\title{
THE ECONOMIC COMPETITIVENESS AND INCLUSIVE DEVELOPMENT NEXUS: EMPIRICAL EVIDENCE FROM 101 ECONOMIES
}

\author{
Associate Professor Olimpia NEAGU, Ph.D \\ Associate Professor Mircea Constantin TEODORU, Ph.D \\ "Vasile Goldiş" Western University of Arad \\ e-mail: olimpian2005@yahoo.com
}

(Received: April 2018; Accepted: July 2018)

\begin{abstract}
The paper explores the association between economic competitiveness and inclusive development in 101 economies based on data provided by the 2018 World Economic Forum reports. Coefficients of ranks correlation and cluster analysis are used in this view.

The values of Competitiveness Index and of Inclusive Development Index delivered by the 2018 World Economic Forum reports are considered. Economic competitiveness and inclusive development are positively associated in our sample of 101 economies and the correlation is stronger in the emerging countries as in the group of advanced economies. Among the advanced economies the mean scores of GCI and IDI are higher than in the group of emerging countries showing a better coordination of economic and institutional factors driving competitivity as well as inclusiveness. Countries belonging to a geographical region/continent/economic group are not grouped in the same cluster, emphasizing disparities among countries at regional/continental/economic group level. In the group of emerging economies, the disparities regarding competitivity and inclusiveness are lower than those among the advanced economies, the clusters are closer to one another and they are more homogeneous. Greater competitivity and economic performance can generate socioeconomic inequity that should be corrected through appropriate economic and social policy measures aimed to lead to wider distrbution of income and social inclusiveness.
\end{abstract}

Key words: economic competitiveness, inclusive development, welfare economics, cluster analysis

JEL Codes: O10, D60, C38

\section{Introduction}

The concern of economists and researchers as well as policymakers for inclusive societies and how economic output or prosperity can be shared with more individuals is arising from several societal problems to be addressed: sustainability of growth, climate change, increase of poverty and disparities in income, the need to ensure social safety.

\footnotetext{
$S$ sciendo Studia Universitatis "Vasile Goldis" Arad. Economics Series Vol 28 Issue 3/2018 ISSN: 1584-2339; (online) ISSN: 2285 - 3065 
Neagu, O., Teodoru, M.C. (2018)

The economic competitiveness and inclusive development nexus: empirical evidence from 101 economies

The global crisis and its impact on economic activity renewed the focus of the research on determinants of growth and links between sustainable growth and income inequality. Can be growth sustainable when social inequality persists? It is the question to be answered.

There is a huge literature on economic growth and income distribution. For example, several studies of IMF shows the growth is more sustainable when is robustly associated with more equality in income distribution. Also, some IMF studies found that average growth on long term is higher with more initial equality and others say that an increase in equality tends to generate a lower growth in the next term (Berg\&Ostry, 2011).

The recent IMF attention of research shifted from macroeconomic effects of inequality to inclusive growth. In the IMF view, growth remains critical but employment is the basis for people to feel included in the society, all categories of population should have the opportunity to share the prosperity in a country and growth have to shared not just among the present generations but also with the future ones (Loungani, 2017).

Durable societies are those with greater equality. The analysis of growth and inclusion cannot be separated; they are the faces of the same coin (Berg\&Ostry, 2011).

The 2017 Report of World Economic Forum regarding inclusive growth and development, is based on the answer to the question: how to turn the vicious circle of low growth and rising inequality in the world economy to a "virtous one in which greater social inclusion and stronger and more sustainable growth reinforce each other" (WEF, 2017, p.vii). In order to give a framework for economic policy and performance metrics, the report provides a practical guide for policy makers to build their strategies aiming to strengthen the synergy between the process of economic growth and a wider social participation in the process and benefits of such growth.

Another focus of economic research in the last 20 years, the economic competitiveness -its drivers and impact- became the subject of yearly reports of World Economic Forum, is recognised as main driver of growth in advanced and emerging economies.

Taking into account the above considerations, the aim of the present paper is to identify the disparities among world economies regarding their inclusive development and competitiveness level and to investigate if there is a correlation between these two variables.

The paper is organised as follows: after the literature review regarding the inclusive growth concept, inclusive development index and global competitiveness index calculated by World Economic Forum, the third section is dedicated to Data and

2 Studia Universitatis "Vasile Goldis" Arad. Economics Series Vol 28 Issue 3/2018 $\checkmark$ sciendo ISSN: 1584-2339; (online) ISSN: $2285-3065$

Web: publicatii.uvvg.ro/index.php/studiaeconomia.Pages $1-19$ 
Neagu, O., Teodoru, M.C. (2018)

The economic competitiveness and inclusive development nexus: empirical evidence from 101 economies

Methodology and fourth section exposes the Main findings of the research and the last sections are dedicated to Discussion and Conclusions.

\section{Literature review}

\subsection{Inclusive growth concept}

The concept of inclusive growth emerged in the economic literature and research as a result of the conclusion that the increase of income (GDP) does not necessarily means growth, especially in developing countries experiencing growth process associated with high levels of unemployment, rates of poverty and wide income disparities.

A first attempt to define inclusive growth belongs to the experts of Asian Development Bank (2007). They provided a definition and a methodology to capture the inclusive growth based on the social opportunity function. The outcomes of inclusive growth are: sustainable and equitable growth, social inclusion, empowerment and security. The economic growth has to be rapid and sustained in order to be broad-absed across sector/regions and inclusive for the labour force, including all vulnerable groups of population. Social inclusion means the dissolution of institutional barriers and increase of access for all population categories to development opportunities. Empowerment means enabling citizens to participate in the growth process and Security is referring to the management of social riskes (country, institutional, governance, political, military etc). Based on these foreseen outcomes, the three key measures for inclusive growth are: employment and productivity, development in human capabilities and social safety nets and targeted intervention (Ali\&Son, 2007).

Inclusive growth is defined by Ianchovichina and Gable (2012) as the one aiming to sustainably and rapidly reducing poverty and inequality and ensuring that all the labour force contribute and benefit from the economic growth process. In another point of view, the growth inclusiveness means that the income in less developed countries grow relatively faster and no social group is left behind in the economic growth process (Werner, 2012).

Inclusive growth is very difficult to be defined due to the fact that we have to take into consideration several aspects (economic, institutional, political orientation, public policies, governance, social, environmental), perhaps it is country specific (Addison \&Nino-Zarazua, 2012).

Recent studies show that inclusive growth is associated with financial development and human capital (Swamy, 2010; Ayide \&Yinusa, 2016; Oyionlola\& Adedeji, 2017 ) or with a higher level of human capital accumulation (expenditures for education and health) and natural resources rent (Raheem et al., 2018). 


\subsection{Inclusive Development}

The slow progress in living standards and widening inequality led to the emergence of a worldwide consensus regarding the need for a more inclusive and sustainable model of growth promoting high living standards for all (WEF, 2017). The World Economic Forum System Initiative on Shaping the Future of Economic Progress introduced in 2017 an economic policy framework and performance metrics with 15 areas of structural economic policy and institutional strengths that can contribute to the diffusion of gains in living standards, named Inclusive Development Index (IDI).

In 2018, The World Economic Forum System Initiative on Shaping the Future of Economic Progress suggests that in the age of the Fourth Industrial Revolution a new economic growth model is required, a model that places peopled and living standards at the centre of national economic policy and international economic integration (WEF, 2018).

\subsection{Global Competiveness}

The 2017-2018 World Economic Forum Report on Global Competitiveness suggests a human-centric economic progress, a vast majority of people benefitting from it, environmentally sustainable, equitable in creating opportunities for all and not disadvantaging future generation (WEF, 2017-2018). Competitiveness is important in this approach through creating resources for well-being, meaning better education, health, security and higher GDP per capita.

The Global Competitiveness Index (GCI) calculated by WEF experts includes factors driving to a higher productivity, the main determinant of growth on the long run and prosperity.

\section{Data and method}

\subsection{Data}

The data used for our analysis are collected from 2018 WEF Report on competitiveness and 2018 World Economic Forum Report on Inclusive Development Index. The data set includes 101 economies from all over the world, grouped in 29 advanced and 72 emerging economies. This structure takes into consideration that the IDI scores in advanced and emerging economies are not strictly comparable due to different definitions of poverty.

The Inclusive Development Index (IDI) is a composite index calculated by the experts of World Economic Forum, based on three pillars (Growth and Development, Inclusion and Intergenerational Equity and Sustainability) and 12 sub-pillars (GDP per capita, Employment, Labour Productivity, Healthy Life Expectancy, Median Household Income, Poverty Rate, Income Gini, Wealth Gini, 
Adjusted Net Savings, Public Debt (share of GDP), Dependency Ratio and Carbon Intensity of GDP).

The IDI scores are based on 1-7 scale (1=worst, $7=$ best).

The Global Competitiveness Index (GCI) is a composite index also, calculated on the basis of 12 pillars: Institutions, Infrastructure, Macroeconomic Environment, Health and Primary Education, Higher Education and Training, Goods Market Efficiency, Labour market efficiency, Financial Market Development, Technological Readiness, Market Size, Business Sophistication, Innovation.

The GCI scores in a range from 1 to 7.

We selected the values of IDI and GCI for 101 national economies, grouped in: advanced and emerging economies.

\subsection{Ranks correlation}

In order to examine the correlation between the above two indexes, we use the Spearman's rank correlation coefficient and the Kendall's rank correlation.

Spearman's rank correlation is computed on the ranks and average ranks. For any two pairs of ranks, $\left(x_{i}, y_{i}\right)$ and $\left(x_{j}, y_{j}\right)$, where $i \geq 1, j \leq n, \mathrm{n}=$ number of observations, we say that they are concordant if:

$$
\left(x_{i}-x_{j}\right)\left(y_{i}-y_{j}\right)>0
$$

and they are discordant if:

$$
\left(x_{i}-x_{j}\right)\left(y_{i}-y_{j}\right)<0
$$

The score $S=C-D$, where $\mathrm{C}(\mathrm{D})$ is the number of concordant(discordant) pairs. The total number of pairs, $\mathrm{N}$ :

$$
N=\frac{n(n-1)}{2}
$$

In order to compute Kendall's correlation score, we calculate $\tau_{a}$ and $\tau_{b}$ as follows:

$$
\begin{aligned}
\tau_{a} & =\frac{S}{N} \\
\tau_{b} & =\frac{S}{\sqrt{N-U} \sqrt{N-V}} \\
U & =\sum_{i=1}^{N_{1}} \frac{u_{i}\left(u_{i}-1\right)}{2} \\
V & =\sum_{j=1}^{N_{2}} \frac{v_{j}\left(v_{j}-1\right)}{2}
\end{aligned}
$$


where $N_{1}$ is the number of sets of tied $x$ values, $u_{i}$ is the number of tied $x$ values in the $i$-th set; $N_{2}$ is the number of sets of tied $y$ values, $v_{j}$ is the number of tied $y$ values in the $j$-th set.

Under the null hypothesis of independence, the variance of $S$ is exactly.

\subsection{Cluster analysis}

In order to analyse the disparities of GCI and IDI accros world economies, divided in two groups: advanced and emerging economies, we use K-means cluster procedure in SPSS.

We fix the $\mathrm{K}$ number of clusters ( 4 in the group of advanced economies and 8 in the group of emerging economies). The classification is made according to the values of means of the variables.

The method is based on calculation the centroid of a cluster and assignation the variables to a group (cluster) whose mean is closest and then new group means are determined.

A country $i(i=\overline{1, n})$ is assigned to a cluster $C_{j}(j=\overline{1, k})$ with its centroid $K_{j}$ (the closest), where $K_{j}$ is updated as follows:

$$
K_{j}=K_{j}+\frac{1}{n r_{j}}\left(z_{j}-K_{j}\right)
$$

The procedure consists in running an algorithm aiming to maximise an objective function given by:

$$
J=\sum_{j=1}^{k} \sum_{i=1}^{n}\left\|z_{i}^{(j)}-K_{j}\right\|^{2}
$$

where: $\left\|z_{i}^{(j)}-K_{j}\right\|^{2}$ is the distance between $x_{i}^{(j)}$ and the centroid $K_{j}$ of the cluster $C_{j}$.

We will use the ANOVA test to validate the differentiation of clusters takinto into consideration the value of F and Sig. If the value of F (calculated) is higher than F (statistic) and the value of Sig is lower than the significance threshold, then the null hypothesis of equality between the means of clusters is rejected and the differentiation is statistically significant.

\section{Main findings}

Among the 29 advanced economies the GCI and IDI are positively correlated (0.337 Kendall's score and 0.449 Spearman's score) for a statistic significance level of 0.05 (see Appendix, Table 1).

\footnotetext{
$\begin{array}{ll} & \text { Studia Universitatis "Vasile Goldis" Arad. Economics Series Vol } 28 \text { Issue 3/2018 } \\ \text { ISSN: 1584-2339; (online) ISSN: 2285 - } 3065\end{array}$ Web: publicatii.uvvg.ro/index.php/studiaeconomia.Pages $1-19$
} 
Neagu, O., Teodoru, M.C. (2018)

The economic competitiveness and inclusive development nexus: empirical evidence from 101 economies

In the case of emerging economies we found a strong and positive correlation between GCI and IDI (0.533 Kendall's score and 0.710 Spearman's score) statistically significant (sig $=0.000$ ) (see Appendix, Table 2).

The CGI scores among the advanced economies have values from 4.02 to 5.86 with a standard deviation of 0.45 and the IDI score varies from 3.7 to 6.08 and a standard deviation of 0.62 (Appendix, Table 3a).

The ANOVA table (Appendix, Table 3b) shows that the clustering is statistically validated for significance level of 0.01 (the value of Sig is $0.000<0.01$ ).

In the 2017-2018 WEF report on global competitivity, the 29 advanced economies included in our sample are placed on the first 40 positions: Switzerland, USA, Netherlands, Germany, Sweden, United Kingdom, Japan, Finland, Norway, Denmark, New Zealand, Canada, Austria, Luxembourg, Belgium, Australia, France, Ireland, Korea, Iceland, Estonia, Czech Republic, Spain, Portugal and Italy. On the first 30 positions we find 2 countries from the other group, of emerging countries: Malaysia (23) and China (27).

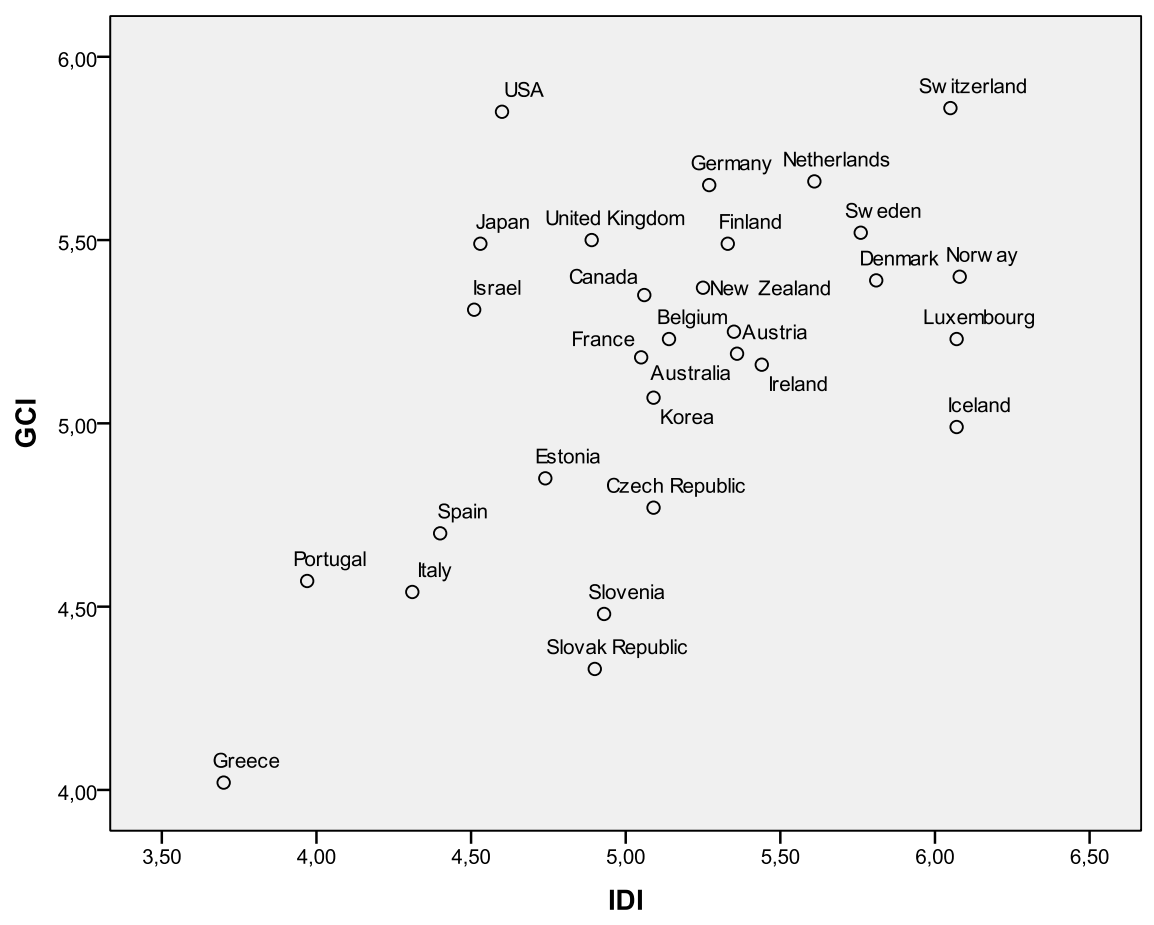

Figure 1 Scatterplot of advanced economies according to GCI and IDI Source: authors' own computation based on WEF data and using SPSS soft 
Regarding the IDI scores (2018 WEF report on inclusive development), the 29 advanced economies are ranked as follows: (1) Norway, (2) Iceland, (3) Luxembourg, (4) Switzerland, (5) Denmark, (6) Sweden, (7) Netherlands, (8) Ireland, (9) Australia, (10) Austria, (11) Finland, (12) Germany, (13) New Zealand, (14) Belgium, (15) Czech Republic, (16) Korea, (17) Canada, (18) France, (19) Slovenia, (20) Slovak Republic, (21) United Kingdom, (22) Estonia, (23) USA, (24) Japan, (25) Israel, (27) Italy, (28) Portugal, (29) Greece.

As we notice in the Figure 1 almost of countries are placed in the right-top corner of the plot, meaning high scores of GCI and IDI (5 to 6). In the right extreme part we notice a set of European countries: Switzerland, Netherlands, Sweden, Denmark, Norway and Luxembourg. In the left extreme bottom corner is situated Greece with low scores of GCI and IDI.

The results of performing K-means procedure are displayed in Appendix, Table 3b. We identified 4 clusters of advanced countries exposed in the Table 1.

Table 1

Clusters among advanced economies

\begin{tabular}{|l|l|c|c|}
\hline \multirow{2}{*}{$\begin{array}{c}\text { Cluster } \\
\text { (number of members) }\end{array}$} & \multicolumn{1}{c|}{ Countries } & \multicolumn{1}{c|}{ Cluster Centers } \\
\cline { 2 - 4 } & \multicolumn{1}{c|}{ GCI } & \multicolumn{1}{c|}{ IDI } \\
\hline Cluster 1 (7) & $\begin{array}{l}\text { Czech Republic, Estonia, Italy, Korea, Slovak } \\
\text { Republic, Slovenia, Spain }\end{array}$ & 4.68 & 4.78 \\
\hline Cluster 2 (10) & $\begin{array}{l}\text { Belgium, Canada, Finland, France, Germany, Israel, } \\
\text { Japan, New Zealand, United Kingdom, USA }\end{array}$ & 5.44 & 4.96 \\
\hline Cluster 3 (10) & $\begin{array}{l}\text { Australia, Austria, Denmark, Iceland, Ireland, } \\
\text { Luxemburg, Netherlands, Norway, Sweden, } \\
\text { Switzerland }\end{array}$ & 5.37 & 5.76 \\
\hline Cluster 4 (2) & Greece, Portugal & 4.3 & 3.84 \\
\hline
\end{tabular}

Source: authors' own computation based on WEF data and using SPSS soft

Cluster 1 includes 6 European countries (Czech Republic, Estonia, Italy, Slovak Republic, Slovenia and Spain) and Korea. The GCI scores range from 4.33 to 5.07 (standard deviation of 0.24) and IDI scores, from 4.31 to 5.09 (standard deviation of 0.31). The best performer is Korea for both variables. Czech Republic is also with the highest IDI score, but as competitiveness is only on the 3rd position in the cluster.

Cluster 2 contains 7 European countries (Belgium, Finland, France, Germany and United Kingdom) and Canada, Israel, Japan, New Zealand, USA. The GCI scores are higher than the GCI mean of the advanced economies group and the IDI scores are around the IDI mean in the group. The best performer in the cluster is USA as CGI score and Finland as IDI score.

Cluster 3 includes 9 European countries (Austria, Denmark, Iceland, Ireland, Luxemburg, Netherlands, Norway, Sweden and Switzerland) and Australia. These 
Neagu, O., Teodoru, M.C. (2018)

The economic competitiveness and inclusive development nexus: empirical evidence from 101 economies

countries have the highest scores for GCI and IDI from the group of advanced economies and from the entire world. Norway is in first place for IDI score and Switzerland for GCI score. The worst performers in the cluster are Iceland for GCI (4.99) and Austria for IDI (5.35).

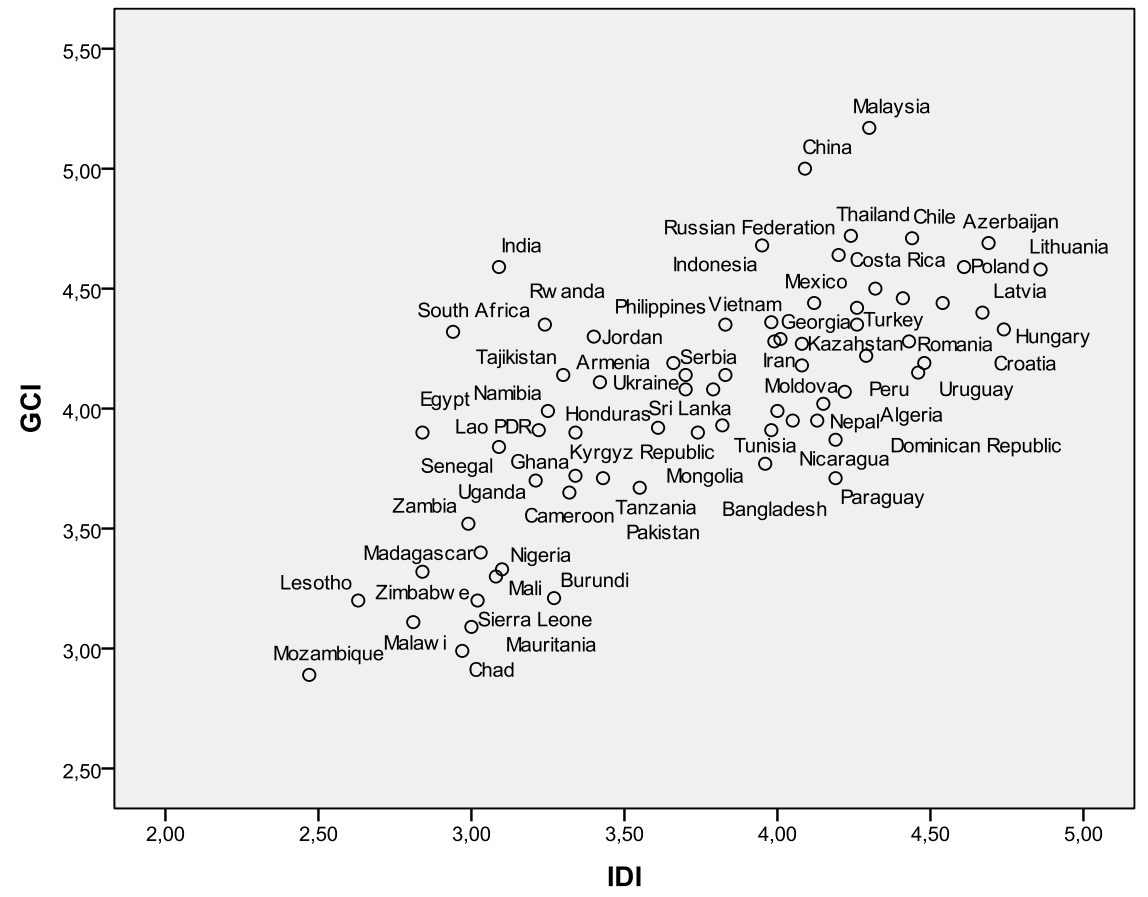

Figure 2 Scatterplot of emerging economies according to GCI and IDI Source: authors' own computation based on WEF data and using SPSS soft

Cluster 4 contains only 2 countries: Greece and Portugal, with IDI scores from 1.7 to 3.97 and GCI scores from 4.02 to 4.57 .

In the group of emerging economies, the GCI scores have values between 2.89 and 5.17 with a standard deviation of 0.48541 . The IDI scores are in range from 2.47 to 4.86 and a standard deviation of 0.58793 (Appendix, Table 4a).

In the 2017-2018 WEF report regarding global competitity, emerging economies are placed in the ranking starting with the 23-rd position (Malaysia), followed by China (27) Thailand (32), Chile (33), Indonesia (36) and Azerbaijan (37).

In the 2018 WEF report regarding inclusive development a separate ranking is made with emerging economies. On the top are placed: Lithuania, Hungary, Azerbaijan, Latvia, Poland, Panama, Croatia, Uruguay, Chile, Romania, Bulgaria, 
Neagu, O., Teodoru, M.C. (2018)

The economic competitiveness and inclusive development nexus: empirical evidence from 101 economies

Costa Rica, Malaysia, Peru and Kazahstan. Their IDI score has a range of 4.86 to 4.26.

A graphical representation of IDI and GCI scores for the 72 emerging economies is displayed in the Figure 2. In the left bottom corner are placed economies with low scores of GCI and IDI (Mozambique, Lesotho, and Malawi) and the right-top corner those with the highest scores: Malaysia, China, Azerbaijan, Latvia, and Lithuania.

The results of running the K-means procedure among emerging countries are displayed in Appendix (Table 2b). We identified 8 clusters presented in the Table 2. The ANOVA tabel (Appendix, Table 4b) shows that the clustering is statistically validated for significance level of 0.01 (the value of $\mathrm{Sig}$ is $0.000<0.01$ ).

Table 2

Clusters among emerging economies

\begin{tabular}{|l|l|c|c|}
\hline \multicolumn{1}{|c|}{$\begin{array}{c}\text { Cluster } \\
\text { number } \\
\text { members) }\end{array}$} & \multicolumn{1}{c|}{ Countries } & \multicolumn{2}{c|}{$\begin{array}{c}\text { Cluster } \\
\text { Centers }\end{array}$} \\
\cline { 2 - 4 } & \multicolumn{1}{|c|}{ GCI } & IDI \\
\hline Cluster 1 (3) & Lesotho, Malawi, Mozambique & 3,07 & 2,64 \\
\hline Cluster 2 (6) & India, Jordan, Rwanda, South Africa, Tajikistan, Ukraine & 4,3 & 3,23 \\
\hline Cluster 3 (11) & $\begin{array}{l}\text { Cameroon, Egypt, Ghana, Honduras, Kyrgyz Republic, Lao PDR, } \\
\text { Namibia, Pakistan, Senegal,Tanzania, Uganda }\end{array}$ & 3,81 & 3,29 \\
\hline Cluster 4 (5) & China, Indonesia, Malayisia, Russian Federation, Thailand & 4,84 & 4,16 \\
\hline Cluster 5 (15) & $\begin{array}{l}\text { Azerbaijan, Bulgaria, Chile, Costa Rica, Croatia, Hungary, } \\
\text { Kazahstan, Latvia, Lithuania, Panama, Peru, Poland, Romania, } \\
\end{array}$ & 4,42 & 4,5 \\
\hline Cluster 6 (11) & $\begin{array}{l}\text { Algeria, Argentina, Bangladesh, Dominican Republic, El Salvador, } \\
\text { Moldova, Mongolia, Nepal, Nicaragua, Paraguay, Tunisia }\end{array}$ & 3,92 & 4,04 \\
\hline Cluster 7 (12) & $\begin{array}{l}\text { Albania, Armenia, Brazil, Colombia, Georgia, Guatemala, Iran, } \\
\text { Mexico, Phillipines, Serbia, Sri Lanka, Vietnam }\end{array}$ & 4,23 & 3,9 \\
\hline Cluster 8 (8) & $\begin{array}{l}\text { Burundi, Chad, Madagascar Mali, Mauritania, Nigeria, Sierra } \\
\text { Leone, Zambia, Zimbabwe }\end{array}$ & 3,26 & 3,03 \\
\hline
\end{tabular}

Source: authors' own computation based on WEF data and using SPSS soft

Cluster 1 includes 3 countries from Sub-Saharian Africa: Lesotho, Malawi and Mozambique. The range of GCI score is from 2.89 to 3.20 and of IDI from 2.47 to 2.81(Appendix, Table 4c). Regarding the competitiveness, the main barriers are related to access to financing, corruption, government instability, infrastructure, low educated work force and bureaucracy. With regard to inclusiveness, these countries are in the last 3 positions in the IDI ranking, with the lowest scores (2.472.81 from a maximum of 4.86).

Cluster 2 contains 6 countries: Tajikistan and Ukraine, Rwanda and South Africa, Indica and Jordan. The GCI scores ranges from 4.11 to 4.59 (standard deviation of 0.17 ) and IDI scores from 2.94 to 3.42 (standard deviation of 0.18) (Appendix, 
Table 4d). In this cluster the lowest score of IDI is registered in South Africa (2.94), folowed by India (3.09), Rwanda (3.24), Tajikistan (3.3), Jordan (3.4) and the best perfomer in the cluster is Ukraine (3.42). Regarding competitiveness, the ranking within the cluser is inversed: the best performer is India (4.59) and the worst is Ukraine (4.11).

Cluster 3 includes 11 countries: Cameroon, Egypt, Ghana, Honduras, Kyrgyz Republic, Lao PDR, Namibia, Pakistan, Senegal, Tanzania and Uganda. The GCI scores range from 3.65 to 3.99 (standard deviation of 0.12 ) and the IDI scores, from 2.84 to 3.61 (standard deviation of 0.21) (Appendix, Table 4e). In this cluster, the best performer as competitiveness is Honduras (3.99) and the worst is Cameroon (3.65), a Sub-Saharian African country that experiences corruption, barriers in accessing funds, infrastructure and low educated work forces as factors hindering its economic competitivity. In Honduras, tax rates, crime, bureaucracy, corruption and policy instability are problematic factors for doing business. Honduras has the 46-th position (of 92) in the ranking of IDI among emerging countries, being the best in class (3.61). Egypt is the worst performer in the cluster as inclusiveness, placed in the 70-th place in the ranking, followed by Senegal (3.09). A group of countries Uganda, Namibia, Lao PDR have IDI scores of 3.223.25 close to the mean of the cluster followed by a group of African countries (Cameroon and Ghana) and Kyrghyz Republic with scores higher than the cluster's mean (3.32-3.34).

Cluster 4 consists of 5 countries: China, Indonesia, Malayisia, Russian Federation and Thailand. The GCI scores range from 4.64 to 5.17 (standard deviation of 0.23 ) and IDO scores from 3.95 to 4.30 (standard deviation of 0.13) (Appendix, Table 4f). The best performer in the cluster is Malaysia, for both variables: competitiveness and inclusive development.

Cluster 5 contains 15 countries: a set of European countries (Bulgaria, Croatia, Hungary, Latvia, Lithuania, Poland, Romania and Turkey), 2 countries from Eurasia (Azerbaijan, Kazahstan) and 5 countries from Latin America (Chile, Costa Rica, Peru, Panama and Uruguay).The GCI scores ranges from 4.64 to 4.71(standard deviation of 0.17) and IDI scores from 4.26 to 4.86 (standard deviation of 0.18) (Appendix, Table 4g). Countries from Latin America experience corruption, bureaucracy, infrastructure problems and low educated work forces as barriers for competitivity. The best performer as inclusive development is Lithuania, placed on the top in the ranking of emerging economies. It is closely followed by Hungary (4.74), Latvia (4.67) and Poland (4.61). In the group of Eurasian countries Azerbaijan is the best placed (4.69). In the group of Latin American countries, Panama is the best performer (4.54). 
Cluster 6 includes 11 countries: from Africa (Algeria, Tunisia) from Asia (Bangladesh, Mongolia, Nepal) Europe(Moldova), Latin America (Argentina, Dominican Republic, El Salvador, Nicaragua, Paraguay). The GCI scores range from 3.71 to 4.07 (standard deviation of 0.10 ) and the IDI scores from 3.74 to 4.22 (standard deviation of 0.15) (Appendix, Table 4h). Algeria is the best performer in the cluster, as inclusiveness and economic competitivity. From the group of countries from Latin America, Paraguay and Dominican Republic have the best score of IDI (4.19) but their scores of economic competitiveness are the lowest in the cluster.

Cluster 7 contains 12 countries from Europe (Albania, Armenia, Georgia, and Serbia), Latin and South America (Brazil, Colombia, Guatemala and Mexico), Asia (Phillipines, Sri Lanka, Vietnam), Middle East (Iran). The scores of GCI range from 4.08 to 4.44 (standard deviation of 0.11 ) and IDI from 3.66 to 4.12 (standard deviation of 0.16) (Appendix, Table 4i). The best score of IDI and GCI are registered in Mexico (4.12; 4.44) and the worst in Guatemala and Sri Lanka.

Cluster 8 includes 11 African countries: Burundi, Chad, Madagascar Mali, Mauritania, Nigeria, Sierra Leone, Zambia and Zimbabwe. The scores of GCI range from 2.99 to 3.52 (standard deviation of 0.16 ) and IDI from 2.84 to 3.27 (standard deviation of 0.11) (Appendix, Table 4j). The best performer in the cluster as inclusiveness is Burundi (3.27) and worst is Zimbabwe (2.84). As competitiveness, Zambia is in the first position (3.52) and Chad (2.99) in the last one.

\section{Discussion}

In the group of advanced countries, 2 non-EU economies are in the top: Switerland, followed by USA. The next 4 positions belong to EU countries: Netherlands, Germany, Sweden, United Kingdom, then Japan and Norway, folowed by Denmark (EU). From the total of 29, 19 are EU members. USA is on last position of the 29 advanced economies as inclusive development.

Among the most inclusive emerging economies, from the first 10 in the ranking, 7 are European countries: Lithuania, Hungary, Azerbaijan, Latvia, Poland, Croatia and Romania and 3 are from Latin America and Carribean (Panama, Uruguay and Chile) and 6 of them are EU members and from the total of 72 in the emerging economies' group, 9 are EU members.

In the top of most inclusive advanced economies, 6 are members of the EU: Luxembourg, Denmark, Sweden, Netherlands, Ireland and Austria, but the best performer, Norway is no EU member.

Switzerland is in the top as competitiveness and in the 4-th place as inclusiveness. Norway is in the top as inclusiveness, but as competitiveness is in the 8 -th position. 
USA has one of the highest score as competitiveness (5.85 of 7), but as inclusiveness, IDI score is 4.6(of 7), being under the mean score of IDI for the group of advanced economies, suggesting an efficiency and effectiveness -driven economy with less concern on social inclusion (poverty, intergenerational equity, dispersion of income in the society).

A great part of emerging countries are experiencing corruption, low educated work forces, inneficiency of institutions, crime (Sub-Saharian Africa, Latin America, East Asia and Pacific).

Malaysia, a country from South-East Asia, is a particular case: with a GCI score of 5.17 it is on the 23-rd place in the world as economic competitivity can be placed in the group of advanced economies, but its IDI score is 4.3 close to the IDI average score of the emerging countries group (4.03).

China has good scores of GCI (5) and IDI (4.9), both above the mean of emerging countries. China is the 27 -th place in world ranking of competitiveness.

\section{Conclusions}

Our study concludes that economic competitiveness and inclusive development are positively associated in our sample of 101 economies and the correlation is stronger in the emerging countries as in the group of advanced economies. This suggests that appropriate public policies and institutional arrangements regarding business environment and stimulating competitiveness should be accompanied by incentives for education and health and poverty reduction measures meant to enlarge the development inclusiveness in the emerging countries.

In advanced economies the mean scores of GCI and IDI are $(5.15 ; 5.11)$ higher than in the group of emerging countries $(4.03 ; 3.75)$, showing a better coordination of economic and institutional factors driving competitivity as well as inclusiveness. The cluster analysis highlights a disparate world economy at this moment, where a group of advanced economies, representing $1 / 3$ of the world economies, has the best performance as competitiveness and inclusive development.

A first conclusion: countries belonging to a geographical region / continent / economic group are not grouped in the same cluster, emphasizing disparities among countries at regional/continental/economic group level (i.e. EU, Europe, G20, Asia, Middle East, and Latin America and Carribean countries, Sub-Saharian Africa). This situation is more frequent in the group of 72 emerging countries, where more regions, economic goups are present.

A second conclusion: in the group of emerging economies, the disparities regarding competitivity and inclusiveness are lower than those among the advanced economies, the clusters are closer to one another and they are more homogeneous. 
The variance of GCI and IDI in these clusters is from 0.013 to 0.03 comparing with advanced economies where the variance is from 0.03 to 0.15 .

A third conclusion: greater competitivity and economic performance can generate socioeconomic inequity that should be be corrected through appropriate economic and social policy measures aimed to lead to a wider distribution of income and social inclusiveness.

We intended to offer a picture of the world economy as regard to competitiveness and inclusive development at this moment. The conclusion is that we have a puzzle of pieces, even we divided the world economies in 2 groups (advanced and emerging). The second group is very diverse as economy driven factors, with several characteristics acting as barriers for economic performance and a wise distribution of income among the participants to the growth process. For example, the main factors hindering the economic competitiveness in the group of emerging economies are: bureaucracy, corruption, and policy and government instability, low educated work force. Factors that hamper inclusive development could be: inefficiency of institutions and public policies, corruption, low labour productivity, extreme poverty, inefficient use of resources.

As further research, a more detalied analysis of the association between economic competitiveness and inclusive development is required, based on territorial criteria or geographical characteristics: Europe, Africa, North America, Latin America and Carribean countries, Asia, South-East Asia, and Middle East. This could generate more valuable recommendations for policy makers for a more equitale distribution of wealth, in particular cases. We think also, when IDI scores will available for several years, to investigate and test econometrical models of the link between economic competitiveness and social inclusiveness.

\section{References}

1. Addison, T., Nino-Zarazua, M. (2012). What is inclusive growth? Nordic-Baltic MDB meeting. UNU WIDER, Helsinki.

2. Ali, I. \& Son, H. (2007). Defining and measuring inclusive growth: application to the Philippines. ERD Working Paper Series no. 98. Asian Development Bank.

3. Ayinde, T.O., Yinusa O.G. (2016). Financial development and inclusive growth in Nigeria: a threshold analysis. Acta Universitatis Danubius, 12(5), 166-189.

4. Berg, A.\& Ostry, A.(2011). Inequality and Unsustainable Growth: Two Sides of the Same Coin?, IMF Staff Discussion Note, SDN/11/08.

5. Ianchovichina, E., Gable, S.L. (2012). What is inclusive growth? In: Arezki R, Pattillo C, Quintyn, M, Zhu, M. (eds). Commodity prices and inclusive growth in low-income countries. International Monetary Fund, Washington, DC.

6. Loungani, P. (2017). The Power of Two: Inclusive growth and the IMF. Intereconomics, Vol.52, Number 2, 92-99. 
Neagu, O., Teodoru, M.C. (2018)

The economic competitiveness and inclusive development nexus: empirical evidence from 101 economies

7. Oyionlola, M.A. \& Adedeji, A. (2017), Human capital, financial sector development and inclusive growth in sub-saharian Africa. Economic Change and Restructuring, 1-24. https://link.springer.com/article/10.1007/s10644-017-9217-2 Accesed 17 June 2018 8. Raheem, I.D., Kazeem. O.I., Adedeji, A.A. (2018). Inclusive growth, human capital development and natural resource rent in SSA. Economic Change and Restructuring, Vol.51 Issue 1, 29-48.

9. Swamy, V. (2010). Financial development and inclusive growth: impact of government intervention in prioritised credit. Zagreb International Revue of Economics and Business, 13(2), 55-72.

10. Warner, A. (2012). Inclusive growth in natural resource intensive countries. In: Arezki R, Pattillo, C., Quintyn. M., Zhu, M. (eds). Commodity prices and inclusive growth in lowincome countries. International Monetary Fund, Washington, DC.

11. World Economic Forum (2017). The inclusive growth and development report 2017. January 2017.

https://www.weforum.org/reports/the-inclusive-growth-and-development-report-2017 Accessed 21 June 2018

12. World Economic Forum (2017).The Global Competitiveness Report 2017-2018.

https://www.weforum.org/reports/the-global-competitiveness-report-2017-2018 Accessed 22 June 2018

13. World Economic Forum (2018). The Inclusive Development Index 2018. Summary and Data Highlights. January 2018.

https://www.weforum.org/reports/the-inclusive-development-index-2018 Accessed 22 June 2018

Appendix Table 1

Ranks correlations among advanced economies

\begin{tabular}{|c|c|c|c|c|}
\hline \multirow{2}{*}{ Kendall's tau_b } & & & GCI & IDI \\
\hline & \multirow[t]{3}{*}{ GCI } & Correlation Coefficient & 1,000 & $337^{*}$ \\
\hline & & Sig. (2-tailed) &. & ,011 \\
\hline & & $\mathrm{N}$ & 29 & 29 \\
\hline & \multirow[t]{3}{*}{ IDI } & Correlation Coefficient &, $337^{*}$ & 1,000 \\
\hline & & Sig. (2-tailed) & ,011 & $\cdot$ \\
\hline & & $\mathrm{N}$ & 29 & 29 \\
\hline \multirow[t]{6}{*}{ Spearman's rho } & \multirow[t]{3}{*}{ GCI } & Correlation Coefficient & 1,000 & $449^{*}$ \\
\hline & & Sig. (2-tailed) & & ,015 \\
\hline & & $\mathrm{N}$ & 29 & 29 \\
\hline & \multirow[t]{3}{*}{ IDI } & Correlation Coefficient & $449^{*}$ & 1,000 \\
\hline & & Sig. (2-tailed) & 015 & \\
\hline & & $\mathrm{N}$ & 29 & 29 \\
\hline
\end{tabular}

*. Correlation is significant at the 0.05 level (2-tailed).

Source: authors' computation using SPSS statistic software 19 
Neagu, O., Teodoru, M.C. (2018)

The economic competitiveness and inclusive development nexus: empirical evidence from 101 economies

Table 2

Ranks correlations among emerging countries

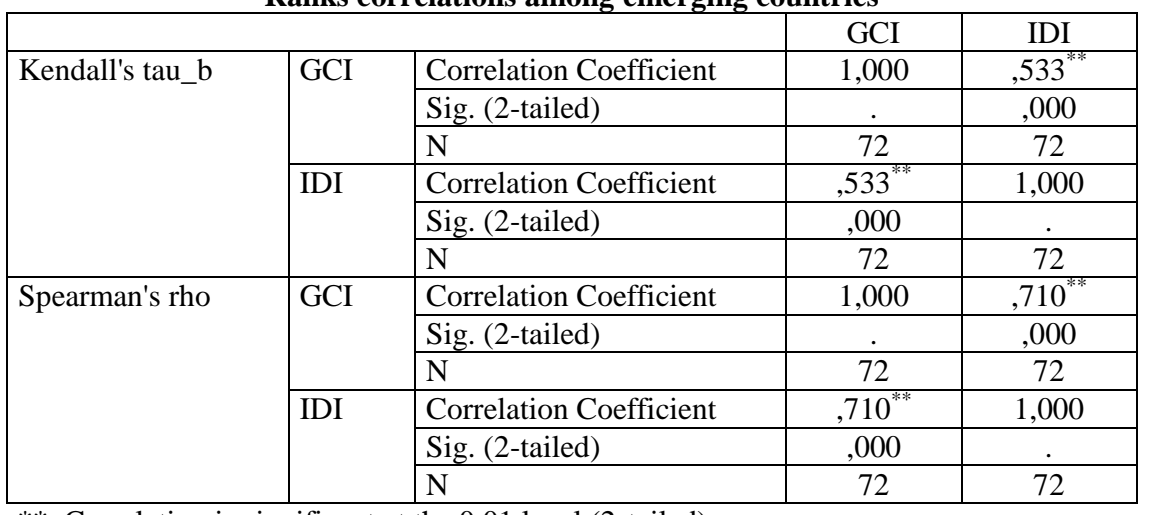

**. Correlation is significant at the 0.01 level (2-tailed).

Source: authors' computation using SPSS statistic software 19

Table 3a

Descriptive statistics of advanced economies

\begin{tabular}{|l|c|c|c|c|c|c|c|c|}
\hline & $\mathrm{N}$ & Range & Minimum & Maximum & \multicolumn{2}{|c|}{ Mean } & Std. Deviation & Variance \\
\cline { 2 - 9 } & Statistic & Statistic & Statistic & Statistic & Statistic & Std Error & Statistic & Statistic \\
\hline GCI & 29 & 1,84 & 4,02 & 5,86 & 5,1517 &, 08473 &, 45630 &, 208 \\
\hline IDI & 29 & 2,38 & 3,70 & 6,08 & 5,1159 &, 11538 &, 62134 &, 386 \\
\hline
\end{tabular}

Results of K-means clustering among advanced economies

Table 3b

Final Cluster Centers

\begin{tabular}{|l|r|r|r|r|}
\hline \multirow{2}{*}{} & \multicolumn{5}{|c|}{ Cluster } \\
\cline { 2 - 5 } & 1 & 2 & \multicolumn{1}{c|}{3} & 4 \\
\hline GCI & 4,68 & 5,44 & 5,37 & 4,30 \\
\hline IDI & 4,78 & 4,96 & 5,76 & 3,84 \\
\hline
\end{tabular}

\begin{tabular}{|l|c|c|c|c|c|c|}
\hline \multirow{2}{*}{ ANOVA } \\
\cline { 2 - 5 } & Mean Square & df & Mean Square & df & F & \multirow{2}{*}{ Sig. } \\
\hline GCI & 1,447 & 3 &, 060 & 25 & 24,320 &, 000 \\
\hline IDI & 2,818 & 3 &, 094 & 25 & 29,900 &, 000 \\
\hline
\end{tabular}

Number of Cases in each Cluster

\begin{tabular}{|l|l|r|}
\hline \multirow{5}{*}{ Cluster } & 1 & 7,000 \\
\cline { 2 - 3 } & 2 & 10,000 \\
\cline { 2 - 3 } & 3 & 10,000 \\
\cline { 2 - 3 } & 4 & 2,000 \\
\hline Valid & 29,000 \\
\hline
\end{tabular}


Neagu, O., Teodoru, M.C. (2018)

The economic competitiveness and inclusive development nexus: empirical evidence from 101 economies

Table 3c

\begin{tabular}{|l|c|c|c|c|c|c|c|c|}
\hline \multicolumn{10}{|c|}{ Descriptive statistics of cluster 1 -advanced economies } \\
\cline { 2 - 9 } & N & Range & Minimum & Maximum & \multicolumn{2}{|c|}{ Mean } & $\begin{array}{c}\text { Std. } \\
\text { Deviation }\end{array}$ & Variance \\
\cline { 2 - 9 } & Statistic & Statistic & Statistic & Statistic & Statistic & Std. Error & Statistic & Statistic \\
\hline GCI & 7 &, 74 & 4,33 & 5,07 & 4,6771 &, 09405 &, 24884 &, 062 \\
\hline IDI & 7 &, 78 & 4,31 & 5,09 & 4,7800 &, 11912 &, 31517 &, 099 \\
\hline
\end{tabular}

Table 3d

Descriptive statistics of cluster 2 -advanced economies

\begin{tabular}{|l|c|c|c|c|c|c|c|c|}
\hline & & & & \multicolumn{2}{|c|}{} & $\begin{array}{c}\text { Std. } \\
\text { Deviation }\end{array}$ & Variance \\
\cline { 2 - 9 } & Statistic & Statistic & Statistic & Statistic & Statistic & Std. Error & Statistic & Statistic \\
\hline GCI & 10 &, 67 & 5,18 & 5,85 & 5,4420 &, 06345 &, 20065 &, 040 \\
\hline IDI & 10 &, 82 & 4,51 & 5,33 & 4,9630 &, 09941 &, 31436 &, 099 \\
\hline
\end{tabular}

Descriptive statistics of cluster 3 -advanced economies

\begin{tabular}{|l|c|c|c|c|c|c|c|c|}
\hline & & & & \multicolumn{2}{|c|}{} & $\begin{array}{c}\text { Std. } \\
\text { Deviation }\end{array}$ & Variance \\
\cline { 2 - 9 } & Statistic & Statistic & Statistic & Statistic & Statistic & Std. Error & Statistic & Statistic \\
\hline GCI & 10 &, 87 & 4,99 & 5,86 & 5,3650 &, 08183 &, 25877 &, 067 \\
\hline IDI & 10 &, 73 & 5,35 & 6,08 & 5,7600 &, 09628 &, 30445 &, 093 \\
\hline
\end{tabular}

Descriptive statistics of cluster 4 -advanced economies

\begin{tabular}{|l|c|c|c|c|c|c|c|c|}
\hline & & & & \multicolumn{2}{|c|}{} & $\begin{array}{c}\text { Std. } \\
\text { Deviation }\end{array}$ & Variance \\
\cline { 2 - 9 } & Statistic & Statistic & Statistic & Statistic & Statistic & Std. Error & Statistic & Statistic \\
\hline GCI & 2 &, 55 & 4,02 & 4,57 & 4,2950 &, 27500 &, 38891 &, 151 \\
\hline IDI & 2 &, 27 & 3,70 & 3,97 & 3,8350 &, 13500 &, 19092 &, 036 \\
\hline
\end{tabular}

Descriptive statistics of emerging economies

Table 4a

\begin{tabular}{|l|r|r|r|r|r|r|r|r|}
\hline \multirow{2}{*}{} & \multicolumn{1}{|c|}{$\mathrm{N}$} & \multicolumn{1}{c|}{ Range } & Minimum & Maximum & \multicolumn{2}{|c|}{ Mean } & $\begin{array}{c}\text { Std. } \\
\text { Deviation }\end{array}$ & Variance \\
\cline { 2 - 9 } & Statistic & Statistic & Statistic & Statistic & Statistic & Std. Error & Statistic & Statistic \\
\hline GCI & 72 & 2,28 & 2,89 & 5,17 & 4,0371 &, 05721 &, 48541 &, 236 \\
\hline IDI & 72 & 2,39 & 2,47 & 4,86 & 3,7533 &, 06929 &, 58793 &, 346 \\
\hline
\end{tabular}

Results of K-means clustering among emerging economies

Table 4b Final Cluster Centers

\begin{tabular}{|l|l|l|l|l|l|l|l|l|}
\hline & \multicolumn{10}{|c|}{ Cluster } \\
\cline { 2 - 10 } & 1 & 2 & 3 & 4 & 5 & 6 & 7 & 8 \\
\hline GCI & 3,07 & 4,30 & 3,81 & 4,84 & 4,42 & 3,92 & 4,23 & 3,26 \\
\hline IDI & 2,64 & 3,23 & 3,29 & 4,16 & 4,50 & 4,04 & 3,90 & 3,03 \\
\hline
\end{tabular}

S sciendo Studia Universitatis "Vasile Goldis" Arad. Economics Series Vol 28 Issue 3/2018 
Neagu, O., Teodoru, M.C. (2018)

The economic competitiveness and inclusive development nexus: empirical evidence from 101 economies

\begin{tabular}{|l|r|r|r|r|r|c|}
\hline \multicolumn{1}{|c|}{ ANOVA } \\
\cline { 2 - 5 } & \multicolumn{2}{|c|}{ Cluster } & \multicolumn{2}{c|}{ Error } & & \\
\cline { 2 - 5 } & $\begin{array}{c}\text { Mean } \\
\text { Square }\end{array}$ & df & $\begin{array}{c}\text { Mean } \\
\text { Square }\end{array}$ & df & \multicolumn{1}{c|}{ F } & Sig. \\
\hline GCI & 2,184 & 7 &, 023 & 64 & 96,941 &, 000 \\
\hline IDI & 3,236 & 7 &, 030 & 64 & 109,631 &, 000 \\
\hline
\end{tabular}

Number of Cases in each Cluster

\begin{tabular}{|c|c|c|}
\hline Cluster & 1 & 3,000 \\
\cline { 2 - 3 } & 2 & 6,000 \\
\cline { 2 - 3 } & 3 & 11,000 \\
\cline { 2 - 3 } & 4 & 5,000 \\
\cline { 2 - 3 } & 5 & 15,000 \\
\cline { 2 - 3 } & 6 & 11,000 \\
\cline { 2 - 3 } & 7 & 12,000 \\
\cline { 2 - 3 } & 8 & 9,000 \\
\hline Valid & & 72,000 \\
\hline
\end{tabular}

Table 4c

Descriptive statistics of cluster 1 -emerging economies

\begin{tabular}{|l|r|r|r|r|r|r|r|r|}
\hline & \multicolumn{1}{|c|}{$\mathrm{N}$} & \multicolumn{1}{c|}{ Range } & \multicolumn{1}{c|}{ Minimum } & Maximum & \multicolumn{2}{|c|}{ Mean } & Std. Deviation & Variance \\
\cline { 2 - 9 } & Statistic & Statistic & Statistic & Statistic & Statistic & Std. Error & Statistic & Statistic \\
\hline GCI & 3 &, 31 & 2,89 & 3,20 & 3,0667 &, 09207 &, 15948 &, 025 \\
\hline IDI & 3 &, 34 & 2,47 & 2,81 & 2,6367 &, 09821 &, 17010 &, 029 \\
\hline
\end{tabular}

Table 4d

Descriptive statistics of cluster 2 -emerging economies

\begin{tabular}{|l|c|c|c|c|c|c|c|c|}
\hline & $\mathrm{N}$ & Range & Minimum & Maximum & \multicolumn{2}{|c|}{ Mean } & Std. Deviation & Variance \\
\cline { 2 - 9 } & Statistic & Statistic & Statistic & Statistic & Statistic & Std. Error & Statistic & Statistic \\
\hline GCI & 6 &, 48 & 4,11 & 4,59 & 4,3017 &, 07040 &, 17244 &, 030 \\
\hline IDI & 6 &, 48 & 2,94 & 3,42 & 3,2317 &, 07609 &, 18638 &, 035 \\
\hline
\end{tabular}

Descriptive statistics of cluster 3-emerging economies

\begin{tabular}{|l|c|c|c|c|c|c|c|c|}
\hline & $\mathrm{N}$ & Range & Minimum & Maximum & \multicolumn{2}{|c|}{ Mean } & Std. Deviation & Variance \\
\cline { 2 - 9 } & Statistic & Statistic & Statistic & Statistic & Statistic & Std. Error & Statistic & Statistic \\
\hline GCI & 11 &, 34 & 3,65 & 3,99 & 3,8100 &, 03656 &, 12124 &, 015 \\
\hline IDI & 11 &, 77 & 2,84 & 3,61 & 3,2909 &, 06402 &, 21234 &, 045 \\
\hline
\end{tabular}

Descriptive statistics of cluster 4-emerging economies

Table 4f

\begin{tabular}{|l|c|c|c|c|c|c|c|c|}
\hline & $\mathrm{N}$ & Range & Minimum & Maximum & \multicolumn{2}{|c|}{ Mean } & Std. Deviation & Variance \\
\cline { 2 - 9 } & Statistic & Statistic & Statistic & Statistic & Statistic & Std. Error & Statistic & Statistic \\
\hline GCI & 5 &, 53 & 4,64 & 5,17 & 4,8420 &, 10356 &, 23156 &, 054 \\
\hline IDI & 5 &, 35 & 3,95 & 4,30 & 4,1560 &, 06185 &, 13831 &, 019 \\
\hline
\end{tabular}


Neagu, O., Teodoru, M.C. (2018)

The economic competitiveness and inclusive development nexus: empirical evidence from 101 economies

Descriptive statistics of cluster 5-emerging economies

Table 4g

\begin{tabular}{|l|c|c|c|c|c|c|c|c|}
\hline & $\mathrm{N}$ & Range & Minimum & Maximum & \multicolumn{2}{|c|}{ Mean } & Std. Deviation & Variance \\
\cline { 2 - 9 } & Statistic & Statistic & Statistic & Statistic & Statistic & Std. Error & Statistic & Statistic \\
\hline GCI & 15 &, 56 & 4,15 & 4,71 & 4,4207 &, 04465 &, 17294 &, 030 \\
\hline IDI & 15 &, 60 & 4,26 & 4,86 & 4,4973 &, 04761 &, 18441 &, 034 \\
\hline
\end{tabular}

Table 4h

Descriptive statistics of cluster 6-emerging economies

\begin{tabular}{|l|c|c|c|c|c|c|c|c|}
\hline & $\mathrm{N}$ & Range & Minimum & Maximum & \multicolumn{2}{|c|}{ Mean } & Std. Deviation & Variance \\
\cline { 2 - 9 } & Statistic & Statistic & Statistic & Statistic & Statistic & Std. Error & Statistic & Statistic \\
\hline GCI & 11 &, 36 & 3,71 & 4,07 & 3,9155 &, 03143 &, 10425 &, 011 \\
\hline IDI & 11 &, 48 & 3,74 & 4,22 & 4,0391 &, 04745 &, 15738 &, 025 \\
\hline
\end{tabular}

Descriptive statistics of cluster 7-emerging economies

Table 4i

\begin{tabular}{|l|c|c|c|c|c|c|c|c|}
\hline & $\mathrm{N}$ & Range & Minimum & Maximum & \multicolumn{2}{|c|}{ Mean } & Std. Deviation & Variance \\
\cline { 2 - 9 } & Statistic & Statistic & Statistic & Statistic & Statistic & Std. Error & Statistic & Statistic \\
\hline GCI & 12 &, 36 & 4,08 & 4,44 & 4,2333 &, 03351 &, 11610 &, 013 \\
\hline IDI & 12 &, 46 & 3,66 & 4,12 & 3,8975 &, 04761 &, 16493 &, 027 \\
\hline
\end{tabular}

Descriptive statistics of cluster 8-emerging economies

Table 4j

\begin{tabular}{|l|c|c|c|c|c|c|c|c|}
\hline & $\mathrm{N}$ & Range & Minimum & Maximum & \multicolumn{2}{|c|}{ Mean } & Std. Deviation & Variance \\
\cline { 2 - 9 } & Statistic & Statistic & Statistic & Statistic & Statistic & Std. Error & Statistic & Statistic \\
\hline GCI & 9 &, 53 & 2,99 & 3,52 & 3,2622 &, 05338 &, 16014 &, 026 \\
\hline IDI & 9 &, 43 & 2,84 & 3,27 & 3,0333 &, 03859 &, 11576 &, 013 \\
\hline
\end{tabular}

